\title{
Impact of Heavy Duty Vehicle Emissions Reductions on Global Climate
}

\author{
KV Calvin
}

AM Thomson

August 2010

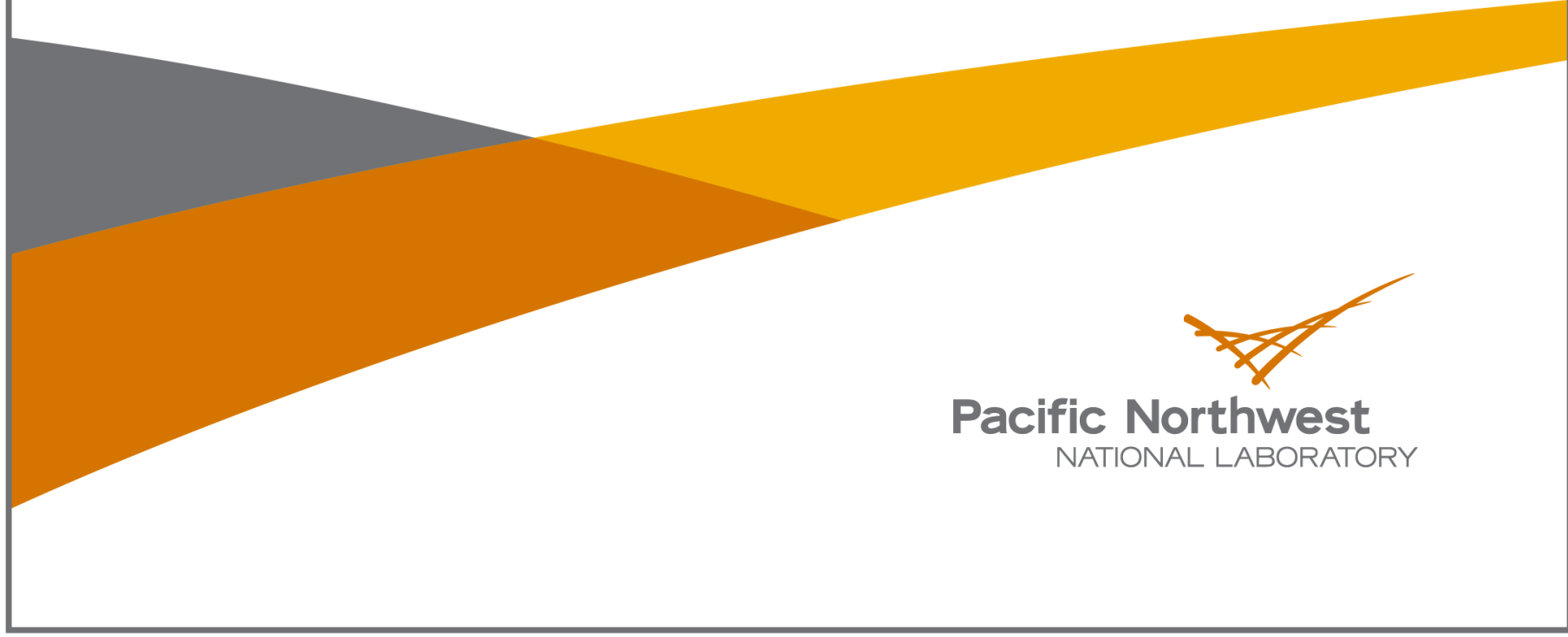




\title{
DISCLAIMER
}

This report was prepared as an account of work sponsored by an agency of the United States Government. Neither the United States Government nor any agency thereof, nor Battelle Memorial Institute, nor any of their employees, makes any warranty, express or implied, or assumes any legal liability or responsibility for the accuracy, completeness, or usefulness of any information, apparatus, product, or process disclosed, or represents that its use would not infringe privately owned rights. Reference herein to any specific commercial product, process, or service by trade name, trademark, manufacturer, or otherwise does not necessarily constitute or imply its endorsement, recommendation, or favoring by the United States Government or any agency thereof, or Battelle Memorial Institute. The views and opinions of authors expressed herein do not necessarily state or reflect those of the United States Government or any agency thereof.

\author{
PACIFIC NORTHWEST NATIONAL LABORATORY \\ operated by \\ BATTELLE \\ for the \\ UNITED STATES DEPARTMENT OF ENERGY \\ under Contract DE-AC05-76RL01830
}

Printed in the United States of America
Available to DOE and DOE contractors from the Office of Scientific and Technical Information,
P.O. Box 62, Oak Ridge, TN 37831-0062;
ph: (865) 576-8401
fax: $(865) 576-5728$
email: reports@adonis.osti.gov

\footnotetext{
Available to the public from the National Technical Information Service, U.S. Department of Commerce, 5285 Port Royal Rd., Springfield, VA 22161 ph: (800) 553-6847 fax: $(703) 605-6900$ email: orders@ntis.fedworld.gov online ordering: http://www.ntis.gov/ordering.htm
}

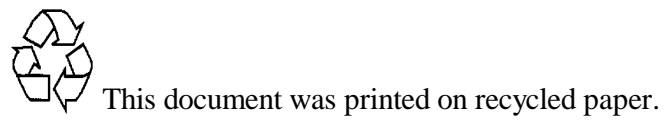




\section{Impact of Heavy Duty Vehicle Emissions Reductions on Global Climate}

Katherine V. Calvin

Allison M. Thomson

August 12, 2010

Prepared for the U.S. Environmental Protection Agency under Contract DE-AC06-76RL01830

Joint Global Change Research Institute 5825 University Research Court, Suite 3500

College Park, Maryland 20740 
The impact of a specified set of emissions reductions from heavy duty vehicles on climate change is calculated using the MAGICC 5.3 climate model. The integrated impact of the following emissions changes are considered: $\mathrm{CO} 2, \mathrm{CH} 4, \mathrm{~N} 2 \mathrm{O}, \mathrm{VOC}, \mathrm{NOx}$, $\mathrm{CO}$, and $\mathrm{SO} 2$. This brief summarizes the assumptions and methods used for this calculation.

\section{Overview of MAGICC}

The MAGICC simple climate model (Wigley and Raper 1992, 2002; Raper et al., 1996) as used in the IPCC Third Assessment Report (Cubasch et al., 2001) was used for these calculations. The version of MAGICC used here uses parameterizations updated for use in the IPCC AR4. The carbon-cycle component of the MAGICC model operates with a balanced global carbon cycle for both historical and future time periods. Input assumptions are specified for net anthropogenic deforestation and ocean fluxes for the decade of the 1980s as well as the strength of temperature-feedbacks. The MAGICC model then adjusts the strength of the carbon-dioxide feedback in order to balance the carbon-cycle over this decade (Wigley 1993). Terrestrial carbon-cycle feedbacks are included as temperature dependent reductions in carbon-pool timescales. A temperature feedback on respiration and gross primary productivity is also included. While the detailed behavior of climate feedbacks on the carbon cycle is undoubtedly complex, the representations used in MAGICC are capable of reproducing the range of results from more complex carbon-cycle models (e.g. Smith and Edmonds 2006). Central values for carbon-cycle parameters were used for this calculation. The impact of pollutant emissions is felt both through changes in atmospheric chemistry that impact the lifetime of methane and some HCFC species, and through changes in tropospheric ozone, a greenhouse gas. These impacts are included using the methodology descried in Wigley, Smith, and Prather (2002).

\section{Method and Data Sources}

The primary data needed for this calculation are: 1) a reference scenario for all emissions and 2) a set of emissions reductions. The reference scenario is the GCAM (formerly MiniCAM) reference (no climate policy) scenario used as the basis for the Representative Concentration Pathway RCP4.5 (Thomson et al., in review). This scenario is used because it contains a comprehensive suite of greenhouse and pollutant gas emissions including carbonaceous aerosols. The GCAM reference scenario is based on scenarios presented in Clarke et al. (2007) with non- $\mathrm{CO}_{2}$ and pollutant gas emissions implemented as described in Smith and Wigley (2006) and land-use change emissions as described in Wise et al. (2009). Base-year information has been updated to the latest available data for the RCP process.

The emissions reductions were supplied by EPA in spreadsheet form (nonGHGbyCY_NHTSAalts_20100803.xls; Climate inputs HD GHG - All alternatives 20100729.xls). Emissions reductions were supplied for 7 pollutant and GHG species: $\mathrm{CO}_{2}, \mathrm{CH}_{4}, \mathrm{CO}, \mathrm{N}_{2} \mathrm{O}$, VOC, $\mathrm{NOx}$, and $\mathrm{SO}_{2}$. 
All emissions reductions were assumed to begin in 2014, with zero emissions change through 2013. For $\mathrm{CO}_{2}, \mathrm{CH}_{4}$, and $\mathrm{N}_{2} \mathrm{O}$, EPA supplied annual emissions reductions and these values were input directly. For $\mathrm{CO}, \mathrm{SO}_{2}$, and $\mathrm{NO}_{\mathrm{x}}$, emissions reductions were only provided for 2018, 2030, and 2050. We linearly scaled emissions reductions between the 0 input value in 2013 and the value supplied for 2018 to produce the reductions for 20142018. A similar scaling was used for 2019-2029 and 2031-2050. The emissions reductions past 2050 were scaled with total US road transportation fuel consumption from the GCAM reference scenario. This was chosen as a simple scale factor given that both direct and upstream emissions changes are included in the emissions reduction scenario provided. Road transport fuel consumption past 2050 does not change significantly and thus emissions reductions remain relatively constant from 2050 through 2100 (see spreadsheet "EPA Emissions - Interpolation.xls" for data and calculations).

The calculation consisted of using the MAGICC model to determine seven pathways for 21 st century greenhouse gas concentrations, radiative forcing, temperature change, and sea-level rise with six different climate sensitivity levels. The first pathway uses the reference scenario emissions. The six additional cases represented policy alternatives as requested by EPA (denoted as EPA Alt 2-7 in the spreadsheets). For these policy cases, the specified emissions changes were subtracted from global emissions for the years 2000-2100. The difference between the reference case and a policy case is the impact of that specific HDV emissions change. Results are reported for $\mathrm{CO}_{2}$ concentration (ppmv), total radiative forcing $\left(\mathrm{W} / \mathrm{m}^{2}\right)$, global mean temperature (degrees $\mathrm{C}$ ), global mean sea level rise (cm), $\mathrm{CH} 4$ concentration (ppbv) and $\mathrm{N} 2 \mathrm{O}$ concentration (ppbv).

\section{Results}

Comparison of results across the six policy scenarios indicates slight reductions from the baseline for the variables of interest. However, very little difference is observed between the different alternative policy scenarios in $\mathrm{CO}_{2}$ concentration, total radiative forcing, global mean temperature and global sea level rise.

The result of the calculations for the scenario "EPA Alt 6" are shown below as different from the reference scenario (see Results_2.xls). Under this emissions reduction policy, global $\mathrm{CO}_{2}$ concentration is reduced by $0.7-0.8 \mathrm{ppmv}$ by 2100 , and radiative forcing is reduced by 0.0053 to 0.0055 in the same time period. The range of reductions in global mean temperature and global sea level rise is larger due to the different climate sensitivity cases considered in MAGICC. 


\section{Change in $\mathrm{CO} 2$ Concentration}

(EPA alt 6 - Reference)

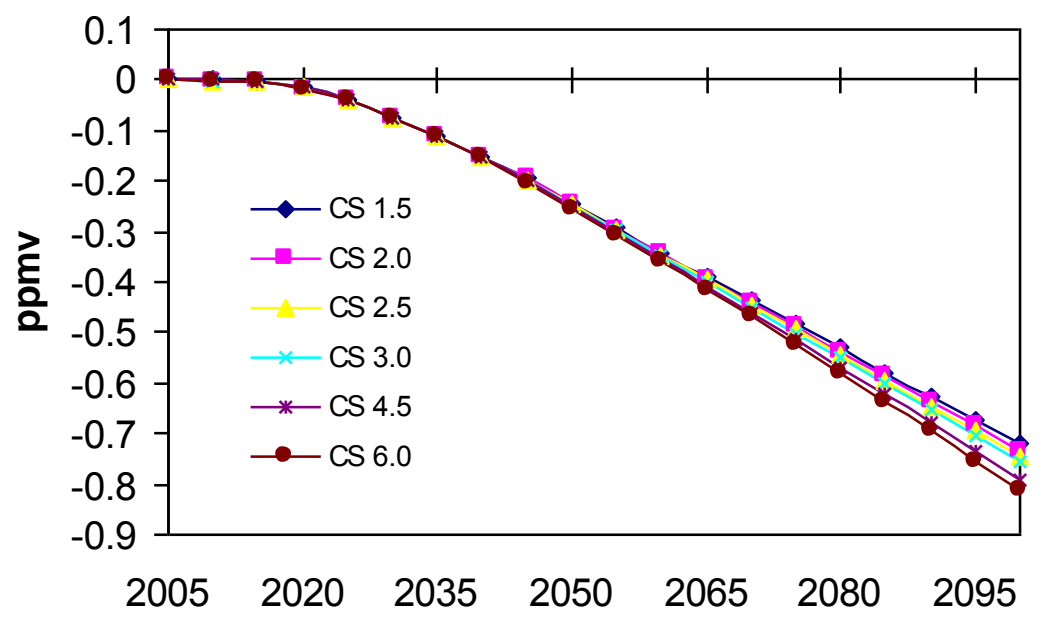

Change in Total Radiative Forcing (EPA alt 6 - Reference)

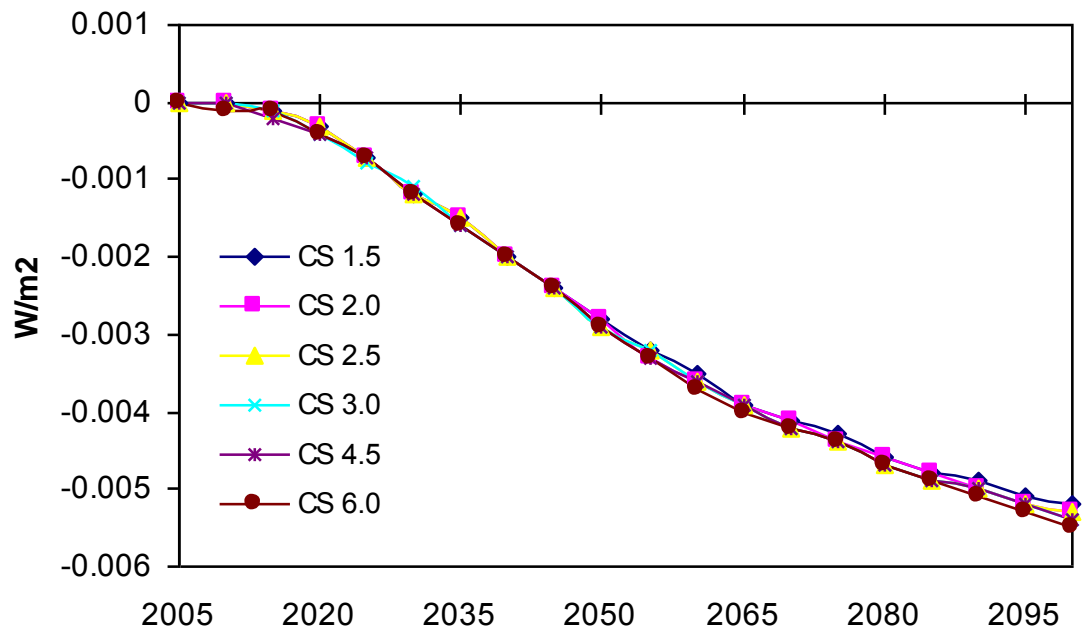



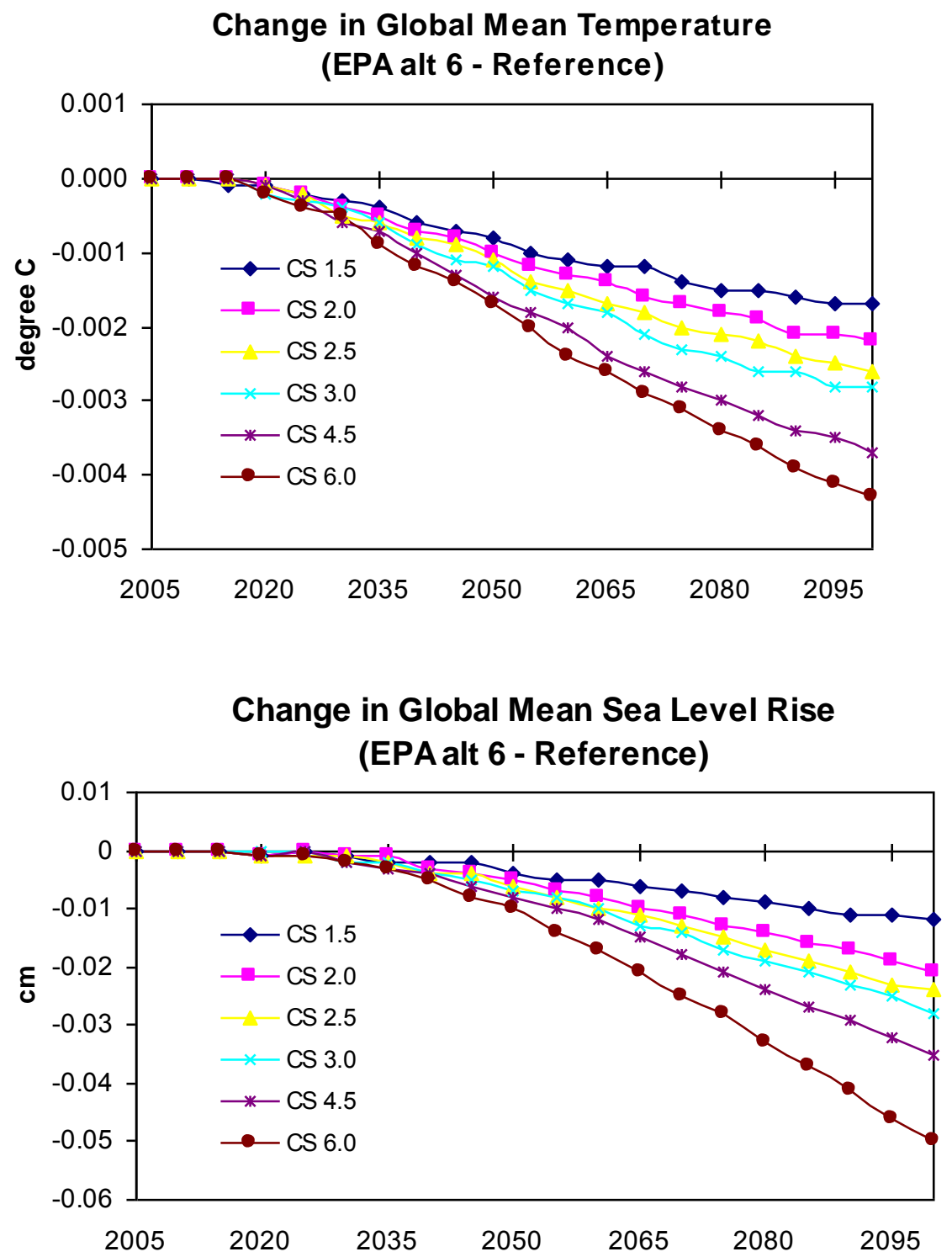

\section{References}

Bond, T. C., D. G. Streets, K. F. Yarber, S. M. Nelson, J.-H. Woo, and Z. Klimont (2004) "A technology-based global inventory of black and organic carbon emissions from combustion” J. Geophys. Res. 109, D14203, doi:10.1029/2003JD003697.

Clarke, L., J. Edmonds, H. Jacoby, H. Pitcher, J. Reilly, R. Richels, (2007) Scenarios of Greenhouse Gas Emissions and Atmospheric Concentrations. Sub-report 2.1A of Synthesis and Assessment Product 2.1 by the U.S. Climate Change Science Program and the Subcommittee on Global Change Research (Department of Energy, Office of Biological \& Environmental Research, Washington, DC., USA, 154 pp.).

Durbin, T.D., J.M. Norbeck, M.R. Smith, and T.J. Truex (1999) "Particulate emission rates from light-duty vehicles in the South Coast Air Quality Management District" Environmental Science and Technology 33 4401-4406. 
Forster, P., V. Ramaswamy, P. Artaxo, T. Berntsen, R. Betts, D.W. Fahey, J. Haywood, J. Lean, D.C. Lowe, G. Myhre, J. Nganga, R. Prinn, G. Raga, M. Schulz and R. Van Dorland (2007) Changes in Atmospheric Constituents and in Radiative Forcing. In: Climate Change 2007: The Physical Science Basis. Contribution of Working Group I to the Fourth Assessment Report of the Intergovernmental Panel on Climate Change [Solomon, S., D. Qin, M. Manning,

Z. Chen, M. Marquis, K.B. Averyt, M.Tignor and H.L. Miller (eds.)]. Cambridge University Press, Cambridge,United Kingdom and New York, NY, USA.

Raper, S.C.B., Wigley T.M.L. and Warrick R.A. 1996. in Sea-Level Rise and Coastal Subsidence: Causes, Consequences and Strategies J.D. Milliman, B.U. Haq, Eds., Kluwer Academic Publishers, Dordrecht, The Netherlands, pp. 11-45.

Smith, Steven J. and J.A. Edmonds (2006) The Economic Implications of Carbon Cycle Uncertainty Tellus B 58 (5), pp. 586-590.

Smith, Steven J. and T.M.L. Wigley (2006) "Multi-Gas Forcing Stabilization with the MiniCAM" Energy Journal (Special Issue \#3).

Wigley, T. M. L. 1993. Balancing the Carbon Budget - Implications for Projections of Future Carbon-Dioxide Concentration Changes Tellus 45B, 409-425.

Wigley, T. M. L. and Raper, S. C. B. 2001. Interpretation of high projections for globalmean warming. Science 293(5529), 451-454.

Wigley, T.M.L. and Raper, S.C.B. 1992. Implications for Climate And Sea-Level of Revised IPCC Emissions Scenarios Nature 357, 293-300.

Wigley, T.M.L. and Raper, S.C.B. 2002. Reasons for larger warming projections in the IPCC Third Assessment Report J. Climate 15, 2945-2952.

Wigley, T.M.L., Steven J. Smith, and M.J. Prather (2002) "Radiative Forcing due to Reactive Gas Emissions" Journal of Climate 15(18), pp. 2690-2696.

Wise, M. A, Calvin, K. V, Thomson, A. M, Clarke, L. E, Bond-Lamberty, B., Sands, R. D, Smith, S. J, Janetos, T. C, Edmonds, J. A (2009) "Implications of Limiting CO2 Concentrations on Land Use and Energy" Science 324 pp. 1183-1186 